\title{
Reforming environmental law: the democratic case for market incentives*
}

\section{Reformando o direito ambiental: o caso democrático para incentivos de mercado}

\author{
Bruce A. Ackerman** \\ Richard B. Stewart***
}

\section{ABSTRACT:}

In this article, the environmental law is discussed under the democratic and market perspectives, in order to present to the reader that it is possible to have more efficiency to the administrative processes of this scenario, and that the market incentives, when properly used, can save billions of dollars each year, helping to balance the budget and the system of pollution regulation.

* Article received on May 13, 2016 and approved on June 14, 2016. Originally published in Columbia Journal of Environmental Law, v. 13, n. 171, 1987-1988. DOI: http://dx.doi. org/10.12660/rda.v272.2016.64295.

** Yale University, New Haven, Connecticut, Estados Unidos. E-mail: bruce.ackerman@yale. edu. Sterling Professor of Law and Political Science, Yale University.

*** New York University, New York, New York, Estados Unidos. E-mail: richard.stewart@nyu. edu. University Professor. John Edward Sexton Professor of Law. Director, Frank J. Guarini Center on Environmental, Energy, and Land Use Law. 


\section{KEYWORDS:}

Administrative efficiency - democracy - environmental law - market incentives

\section{RESUMO:}

Neste artigo, a reforma do direito ambiental é discutida à luz dos valores democráticos e de mercado, no intuito de mostrar ao leitor que é possível trazer mais eficiência aos processos administrativos presentes neste cenário, e que os incentivos de mercado, quando usados de forma criativa, podem economizar bilhões de dólares por ano, auxiliando no controle do orçamento e no sistema de regulação da poluição.

\section{PALAVRAS-CHAVE}

Eficiência administrativa - democracia - direito ambiental - incentivos de mercado

\section{A false dichotomy}

Too much of our domestic debate is dominated by a familiar dichotomy. On the one side, behold the hard-headed partisans of the market, emphasizing the need for efficiency and the dead hand of bureaucracy. On the other side stand the embattled defenders of democracy, emphasizing the reality of nonmarket values and the callousness of the invisible hand. Democracy versus the market: doubtless the conflict is often real enough; and when we must choose, we shall stand with the democrats. But precisely because there are fundamental values on both sides of the versus, we should not be too quick to impale ourselves on the prongs of a false dichotomy. Can markets be designated in ways which enhance, rather than undermine, the reality of democratic self-rule? This is the question that should dominate the agenda for the reform of environmental law. Reform does not require Americans to choose between democracy and efficiency. We can have more of both. The creative use of market incentives will not only save billions of dollars each year, vastly improve administrative efficiency, and even help balance the budget. It will also vastly improve the quality of democratic debate about environmental values, allowing a wider public to address basic issues that the present regulatory system obscures under a flood of technocratic mumbojumbo. 
Our argument proceeds in three stages. First, we summarize the economic failings of the existing system of environmental regulation, as they have been detailed by serious students over the past twenty years. Next, we confront the charge that the theoretical efficiencies of market incentives will be swamped by the impossible administrative demands it imposes on the existing bureaucracy. The fear here is that, flying the banner of "more cleanliness for the buck," market reformers will simply lead us to bureaucratic chaos. Finally, we hope to move beyond these economic and bureaucratic issues to questions of democratic value still more fundamental. Our aim is to suggest how a reformed regulatory system will, over time, promote a public dialogue that will enable a far more meaningful discussion and resolution of the basic choices Americans face in shaping the future of environmental law.

We propose, in short, to convince you that there is such a thing as a free lunch. A reform relying on market incentives is just plain better, in terms of all relevant public values, than the status quo. This is not to say, of course, that nobody will lose by the abandonment of our expensive, cumbersome and undemocratic system. The congressional committees, government bureaucracies, industry and environmental groups that have helped shape the status quo want to see it perpetuated. ${ }^{1}$ Nonetheless, we should not be too impressed by the "iron triangle" against change. As other efforts at regulatory reform suggest, these alliances can disintegrate with remarkable speed as their ideological underpinnings are eroded by a generation of sustained critique. Does a similar fate await environmental law? For twenty years now, we have learned how the present system fails to fulfill the brave hopes expressed by its founders in the 1960s. Rather than sticking with the old mistakes, we can do better, much better. After the blundering Gorsuch years, are the American people ready for serious environmental reform?

\section{The existing system}

The existing system of pollution regulation is primarily based on a best available control technology (BAT) strategy. If an industrial process generates

1 See generally Stewart, The Discontents of Legalism: Ongoing Relations in Administrative Regulation, 1985 Wis. L. Rev. 655. The forces favoring as well as those opposing reform are examined in Meidinger, On Explaining the Development of "Emissions Trading" in U.S. Air Pollution Policy, 7 L. \& Pol'y 447 (1985). 
some non-trivial risk, the responsible plant or industry must install whatever technology is available to reduce or eliminate the risk, so long as the costs of doing so will not shut down the relevant plant or industry. BAT requirements are largely determined through centralized uniform federal regulation. Under the Clean Water Act's BAT strategy, EPA adopts nationally uniform effluent limitations for some 500 different industries. A similar BAT strategy is used in the Clean Air Act for new industrial sources of air pollution, new automobile and industrial sources of toxic air pollutants. ${ }^{2}$ BAT strategies are also widely used in many fields of environmental regulation other than air and water pollution. ${ }^{3}$

BAT was embraced by Congress and administrators in the early 1970s in order to impose immediate, readily-enforceable, federal controls on a relatively few, widespread pollutants, while avoiding widespread industrial shutdowns. Subsequent experience and analysis has demonstrated:

1. Uniform BAT requirements waste many billions of dollars annually ${ }^{4}$ by ignoring variations among plants and industries in the costs of reducing pollution and by ignoring geographic variations in pollution effects. A more cost-effective strategy of risk reduction could free up enormous resources for additional pollution reduction or other purposes.

2. BAT controls, and the litigation which they provoke, impose disproportionate penalties on new products and processes. A BAT strategy typically imposes far more stringent controls on new sources because there is no risk of shutdown. Also, new plants and products must run the gauntlet of lengthy regulatory and legal proceedings to win approval; the resulting

2 Clean Air Act, 42 U.S.C. $\S \S 741$ 1(a)(1). 7412, 7512(a)(3)(A)(i) (1982) (amending 42 U.S.C. $\S \S 1857-58(a)$ (1976)). Under other portions of the Clean Air Act, regulation of existing industrial sources of certain widespread pollutants is based, in theory, on the achievement of uniform federal air quality standards, rather than on the uniform adoption of available technology. See id. $\S \S 7409,7410$. In practice, however, the controls imposed on sources in regions that do not comply with the federal air quality standards are based on "reasonably available control measures" - a form of BAT. See id. § 7502(b)(2).

3 Examples include control of low-level radioactive emissions from normal operation of nuclear power plants and standards for treatment and disposal of toxic substances under the Resource Conservation and Recovery Act. Resource Conservation and Recovery Act. 42 U.S.C. \$§ 6901-87 (1982). Rather than rely on uniform standards requiring that a category of plants or products meet BAT requirements, some environmental regulatory programs use case-by-case screening of particular products or development projects under open-ended criteria such as "unreasonable risk." See Stewart, Regulation, Innovation and Administrative Law: A Conceptual Framework, 69 CALIF. L. REV. 1259, 1265-66 (1981). While our proposals for reform focus on air and water pollution control, we consider briefly their possible application to these other areas of environmental law. See infra note 35 and text accompanying notes 52-53.

4 See infra text accompanying notes 8-14. 
uncertainty and delay discourage new investment. By contrast, existing products and processes can use the legal process to postpone or water down compliance requirements. Also, BAT strategies impose disproportionate burdens on more productive and profitable industries because they can "afford" more stringent controls. This "soak the rich" approach penalizes growth and international competitiveness. ${ }^{5}$

3. BAT controls can ensure the diffusion of established control technologies. But they do not provide strong incentives for the development of new, environmentally superior strategies and may actually discourage their development. Such innovations are essential if we are to maintain economic growth in the long run without simultaneously increasing pollution and other forms of environmental degradation. ${ }^{6}$

4. BAT involves centralized, uniform determination of complex scientific, engineering and economic issues involving the feasibility of controls on hundreds of thousands of pollution sources. Such determinations impose massive information gathering burdens on administrators and provide a fertile ground for litigation, producing reams of technical data, complex adversary rulemaking proceedings and protracted judicial review. Given the high cost of regulatory compliance and the potential gains from litigation brought to defeat or delay regulatory requirements, it is often more cost effective for industry to invest in litigation rather than compliance. ${ }^{7}$

5. A BAT strategy is inconsistent with intelligent priority setting. Simply regulating to the hilt whatever pollutants or problems happen to get on the regulatory agenda may preclude an agency from dealing adequately with

5 On the differential treatment of old and new sources and resulting implications for investment and productivity, see Crandall, The Political Economy of Clean Air. Practical Constraints on White House Review in ENVIRONMENTAL POLICY UNDER REAGAN'S EXECUTIVE ORDER 205, 215-221 (V. Smith ed. 1984); Huber, The Old-New Division in Risk Regulation, 69 VA. L. REV. 1025 (1983); Stewart, supra note 3. For the impact of domestic environmental regulatory policies on United States international competitiveness, see Kalt, The Impact of Domestic Environmental Regulatory Policies on U.S. International Competitiveness, in ENERGY AND ENVTL. POLICY CENTER, JOHN F. KENNEDY SCH. OF GOV'T, HARV. U., DISCUSSION PAPER SERIES E-85-02 (1985). For suggestive evidence that the current BAT system gives a comparative competitive advantage to large plants within a regulated industry, see Pashigian, The Effect of Environmental Regulation on Optimal Plant Size and Factor Shares, 27 J.L. \& ECON. 1 (1984).

6 See J. KRIER \& E. URSIN, POLLUTION AND POLICY $24-27$ (1977); Stewart, supra note 3. For a more optimistic view of the ability of a BAT approach to stimulate social innovation, see Ashford, Ayres \& Stone, Using Regulation to Change the Market for Innovation, 9 HARV. ENVTL. L. REV. 419 (1985).

7 See Stewart, supra note 3; S. MELNICK, REGULATION AND THE COURTS: THE CASE OF THE CLEAN AIR ACT 193-238 (1983). 
other more serious problems that come to scientific attention later. The BAT strategy also tends to reinforce regulatory inertia. Foreseeing that "all or nothing" regulation of a given substance under BAT will involve very large administrative and compliance costs, and recognizing that resources are limited, agencies will seek to limit the number of substances on the agenda for regulatory action. ${ }^{8}$ This indictment is not a piece of idle speculation but the product of years of patient study by lawyers, economists and political scientists. ${ }^{9}$ There are, for example, no less than fifteen careful efforts to estimate this extra cost burden generated by a wide variety of traditional bureaucratic systems used to control a variety of air and water pollutants in different parts of the country. Of the twelve studies of different air pollutants ${ }^{10}$ - ranging from particulates to chlorofluorocarbons-seven indicated that traditional

8 See Harrison, Haig \& Nichols, Benefits Assessment and Environmental Regulation: Case Studies of Hazardous Pollutants, in ENERGY AND ENVTL. POLICY CENTER, JOHN F. KENNEDY SCH. OF GOV'T, HARV. U., DISCUSSION PAPER SERIES E-83-07 (1983); Dorfman, The Lessons of Pesticide Regulation in REFORM OF ENVIRONMENTAL REGULATION 13 (W. Magat ed. 1982); Crandall \& Pormney, Environmental Policy, in NATURAL RESOURCES AND THE ENVIRONMENT: THE REAGAN APPROACH 48-49, 72-73 (P. Portney ed. 1984).

9 For an up-to-date review of relevant sources, see the bibliographies at the end of each chapter compiled by T. TIETENBERG, EMISSIONS TRADING: AN EXERCISE IN REFORMING POLLUTION POLICY (1985). The development of the reformist critique may be traced in ENVIRONMENTAL POLICY UNDER REAGAN'S EXECUTIVE ORDER, supra note 5 (1984); NATURAL RESOURCES AND THE ENVIRONMENT: THE REAGAN APPROACH, supra note 8 (1984); R. CRANDALL, CONTROLLING INDUSTRIAL POLLUTION: THE ECONOMICS AND POLITICS OF CLEAN AIR (1983); S. MELNICK, supra note 7 (1983); R. NOLL \& B. OWEN, THE POLITICAL ECONOMY OF REGULATION: INTEREST GROUPS IN THE REGULATORY PROCESS (1983); INCENTIVE ARRANGEMENTS FOR ENVIRONMENTAL PROTECTION: A CRITICAL EXAMINATION 9 (T. Schelling, ed. 1983); W. Magat, supra note 8 (1982); L. LAVE, STRATEGY OF SOCIAL REGULATION: DECISION FRAMEWORKS FOR POLICY (1981); B. ACKERMAN \& W. HASSLER, CLEAN COAL/ DIRTY AIR (1981); J. KRIER \& E. URSIN, supra note 6 (1977); W. BAUMOL \& W. OATES, THE THEORY OF ENVIRONMENTAL POLICY (1975); B. ACKERMAN, S. ROSE-ACKERMAN, J. SAWYER \& D. HENDERSON, THE UNCERTAIN SEARCH FOR ENVIRONMENTAL QUALITY (1974); J. DALES, POLLUTION OF PROPERTY AND PRICES (1968); A. KNEESE \& B. BOWER, MANAGING WATER QUALITY: ECONOMICS, TECHNOLOGY AND INSTITUTIONS (1968): Stewart. Economics. Environment, and the Limits of Legal Control, 9 HARV. ENVTL. L. REV. 1.7 (1985); Stewart, supra note 3 (1981); Krier, The Irrational National Air Quality Standards: Macro and Micro-Mistakes. 22 UCLA L. REV. 323 (1974); RoseAckerman, Effluent Charges: A Critique, 6 CAN. J. ECON. 512 (1973).

10 For an up-to-date review of empirical research, along with a table that usefully summarizes the results of eleven of the air pollution studies, see T. TIETENBERG, supra note 9. at 39-52. In addition to the eleven studies summarized in Tietenberg's chart, we have found some excellent unpublished work by McGartland \& Oates. See McGartland \& Oates, Marketable Permits for the Prevention of Environmental Deterioration, _ J. OF ENVTL. ECON. \& MGMT. _ (198_) (forthcoming). This study estimates that traditional regulation in the Baltimore area is at least twice as expensive as a least-cost approach. We have therefore counted it among the four studies placed in the second of the three crude categories presented in the text. 
forms of regulation were more than four times more expensive than the leastcost solution; four indicated that they were about seventy-five percent more expensive; and only one suggested a modest cost-overrun of seven percent. ${ }^{11}$ Three studies of water pollution control in five different watersheds also indicate the serious inefficiency of traditional forms of command and control regulation. ${ }^{12}$ These careful studies of selected problems cannot be used to

11 This was the study of sulfate pollution in Los Angeles. Hahn \& Noll, Designing a Market For Tradeable Emission Permits, in W. Magat, supra note 8, at 123-37. Two important factors help account for the anomalous character of the Hahn and Noll findings:

First, in contrast to other areas, the command-and-control strategy in California did not include scrubbers, a very expensive approach. Had California required scrubbers, the potential cost savings would have been higher.

Another reason, of more general applicability, is that the amount of control required [to reach air quality objectives in Los Angeles] is so great that every source is forced to control as much as is economically feasible. By definition, little further control can be undertaken. Therefore the divergence between the command-and-control and least-cost allocation would be small. T. TIETENBERG, supra note 9, at 45 . It should be noted that existing federal law, as presently interpreted, requires the installation of scrubbers on all new coalburning power plants in Los Angeles. See B. ACKERMAN \& W. HASSLER. supra note 9, at 101-103. As a consequence, Tietenberg's first point emphasizes the limited power of Hahn and Noll's conclusions even in the extreme situation posed by Los Angeles.

A recent study by Anderson comes to a less certain conclusion. Anderson, Marketable Pollution Permits and Acid Rain Externalities, 16 CAN. J. ECON. 704 (1983). While it finds that marketable rights schemes could generate significant savings in reaching Cleveland's local sulfur dioxide goals, it reaches a more equivocal conclusion once Cleveland's contribution to the larger North American acid rain problem is taken into account. Given Cleveland's strategic geographic location in the Midwest, any plausible solution to acid rain would require all its polluters to treat at very high levels-so high that the cost difference between marketable rights and a more traditional system would be substantially reduced. In respect to its contribution to acid rain, then, Cleveland seems similar to the case of Los Angeles discussed by Hahn and Noll.

Of course, Cleveland is but one of the many sources of the acid rain problem experienced by Canada and the northeastern United States. Unfortunately, however, Anderson has not yet moved beyond Cleveland to study the cost-saving potential of an acid rain marketable rights scheme for the entire North American acid rain control region. Telephone conversation (September 17, 1985). Thus, his study does not permit any firm conclusion on the cost-saving potential of a marketable rights scheme in the regulatory response to the acid rain problem. As a consequence, we have omitted it from the studies summarized in the text.

12 These water studies are less suggestive than are the air studies. They all have to do with the removal of a single, albeit important, water pollutant: biochemical oxygen demand. Moreover, they do not expressly deal with the precise form of BAT regulation actually used under the present Clean Water Act. Instead, the studies investigate a more primitive form of regulation that does not, like BAT, require different cutbacks from different industries depending on the best available technology in each economic sector. Instead, the traditional regulatory approach used as a benchmark in the water studies simply requires all discharges, regardless of industry, to cut back wasteloads proportionally to reach water quality objectives. This proportionate reduction would be equivalent to BAT only if best available technology in every industry permits all industries to cut back by the same percentage. While BAT often does lead to this result, the proportionality assumption invoked by all existing studies can only serve as a crude approximation of BAT's economic impact. Nonetheless, the existing data does suggest 
estimate precisely the total amount traditional forms of regulation are costing the American people. ${ }^{13}$ Nonetheless, very large sums are at stake. Even if a reformed system could cut costs by "only" one-third, it could save more than $\$ 15$ billion a year from the nation's annual expenditure of $\$ 50$ billion on air and water pollution control. ${ }^{14}$

While it is possible to quibble over one or another of the studies cited in the footnote, their overall tendency is, we think, quite unresistable. No serious student denies that the existing system achieves its cleanup goals at an extraordinarily high cost, and one that will get higher over time. Indeed, the most sophisticated proponents of the status quo defend its virtues in a different way. ${ }^{15}$ They try to persuade us that serious reform will prove so administratively cumbersome as to undermine any effective system of environmental control. However costly the existing system, the system's defenders emphasize that it somehow "works" to produce real environmental improvements. Should we jeopardize these hard-won gains by making new-and administratively impossible-demands upon the now-traditional regulatory system?

the possibility of substantial savings by abandoning BAT, though the overruns are somewhat less substantial than those suggested by the air studies. Four of the computer studies suggest that traditional regulation is more than twice as expensive as the least-cost program; six suggest an overrun in the $40-60 \%$ range; while four indicate extra costs of $12-40 \%$. A summary of these studies appears in T. TIETENBERG, supra note 9, at 42-43.

13 Speaking broadly, the empirical estimates summarized in the text are generated by procedures that overestimate BAT's short-term costs, while underestimating its long-term costs. Thus, on the one hand, the computer models do not generally take into account that many polluters have already sunk capital into treatment facilities that would never have been required under a cost-minimizing regulatory scheme. This leads to an overestimate of the short-term savings of regulatory reform because it ignores that some existing equipment might be operated cheaply in the short run, however inefficient it was to install in the first place. On the other hand, existing cost estimates are generated by static models that do not take into account the BAT regime's depressive effect on the rate of pollution control innovation. See infra text accompanying notes 16-17. As a consequence, even the very large cost-overruns presented in the text underestimate likely realities ten or twenty years in the future. These and other useful interpretive points may be found in Professor Tietenberg's recent review of the evidence. See T. TIETENBERG, supra note 9, at 38-53. We do not think a lengthy elaboration of his discussion is necessary to make our basic point: by even the most conservative reckoning, the economic savings promised by a successful reform are substantial indeed.

14 See OFFICE OF POLICY PLANNING AND EVALUATION, U.S. EPA, THE COST OF CLEAN AIR AND WATER (1984) (estimating expenditures to comply with federal air and water pollution control expenditures in the ten years 1981-1990 at \$525 billion (in constant 1981 dollars)). Moreover, market reforms are applicable to many other kinds of pollution as well. See infa notes 35-36 and accompanying text.

15 See Latin, Ideal Versus Real Regulatory Efficiency: Implementation of Uniform Standards and "Fine Tuning" Regulatory Reform, 37 STAN. L. REV. 1267 (1985). 
This modest plea for workaday virtues is misleading. Reformers do not call for the abandonment of the existing bureaucratic system. Instead, they propose to build upon it. The resulting administrative structure places far fewer demands upon real-world bureaucrats than the present command-andcontrol system of BAT. Or so, at least, we will argue again in the next section.

\section{Reform is realistic}

A BAT system has an implicit environmental goal: achievement of the environmental quality level that would result if all sources installed BAT controls on their discharges. The usual means for implementing this goal are centralized, uniform regulations that command specific amounts of cleanup from specific polluters. When a polluter receives an air or water permit under existing law, the piece of paper does not content itself, in the manner of Polonius, with the vague advice that he "use the best available technology." Instead, the permit tries to be as quantitatively precise as possible, telling each discharger how much of each of the regulated pollutants he may discharge. ${ }^{16}$

Reformers propose to build upon, and do not abandon, this basic permit system. Indeed, they have only two, albeit far-reaching, objections to the existing permit mechanism. First, existing permits are free. This is bad because it gives the polluter no incentive to reduce his wastes below the permitted amount. Second, permits are not transferable. This is bad because polluter A is obliged to cut-back his own wastes even if it is cheaper for him to pay his neighbor B to undertake the extra cleanup instead.

The basic reform would respond to these deficiencies by allowing polluters to buy and sell each other's permits - thereby creating a powerful financial

16 While the text describes the existing system's regulatory objective, in fact the process of writing, monitoring and enforcing permits is the Achilles heel of the BAT strategy. See infra text accompanying notes 25-27. While officials in Washington promulgate regulations that are supposed to govern the operation of every plant in an industry, such regulations must be adapted to the specific and varying conditions of different plants throughout the nation. Thus, the actual writing of permits is often accomplished by low-level state or federal field personnel. These permits are often vague and obsolescent. Pedersen, Why the Clean Air Act Works Badly, 129 U. PA. L. REV. 1059 (1981). Moreover, enforcement of permit conditions is often ineffective. See U.S. GEN. ACCT. OFF., WASTEWATER DISCHARGES ARE NOT COMPLYING WITH EPA CONTROL PERMITS (1983); Roberts \& Farrell, The Political Economy of Implementation: The Clean Air Act and Stationary Sources, in APPROACHES TO CONTROLLING AIR POLLUTION 152 (A. Friedlander ed. 1978). See infra text accompanying notes 17-29 for the reasons we believe that a reformed system of transferable permits will tend to alleviate these problems. 
incentive for those who can clean up most cheaply to sell their permits to those whose treatment costs are highest. This reform will, at one stroke, cure many of the basic defects with existing command-and-control regulation. A system of tradeable rights will tend to bring about a least-cost allocation of control burdens, saving billions of dollars annually. ${ }^{17}$ It will eliminate the disproportionate burdens that BAT imposes on new industries and more productive industries by treating all sources of the same pollutant on the same basis. ${ }^{18}$ It will provide positive economic rewards for the development by those regulated of environmentally superior products and processes. ${ }^{19}$ It will, as we show below, reduce the incentives for litigation and simplify the issues in controversy. ${ }^{20}$

But would allowing the sale of permits lead to a bureaucratic nightmare? Before proceeding to the new administrative burdens marketability will generate, it is wise to pause to consider market-ability's great administrative advantages.

First, it would immediately eliminate most of the information processing tasks that are presently overwhelming the federal and state bureaucracies. No longer would the EPA be required endlessly to hold hearings to determine the best available control technologies in each major industry of the United States, and defend its determinations before the courts; nor would federal and state officials be required to spend vast amounts of time and energy to adapt

17 An emissions trading system tends to achieve a least-cost allocation of control for all sources by forcing them to pay the same price for polluting. In practice, a regulated emission trading market is likely to deviate somewhat from the perfect market ideal, but substantial cost savings will still be achieved. See T. TIETENBERG, supra note 9, at 50-56.

18 Equal treatment of old and new sources will not necessarily lead to shutdowns of old plants. It is true, of course, that old plants may evade clean up under BAT if their profits are too low to bear the expense. Because of concern over shutdown, they are often allowed to discharge large wasteloads that could otherwise be treated at low cost. The tradeable permits strategy, however, can provide the needed financing for cleanup by enabling the old plant to sell its pollution rights to others. Thus, if shutdown does occur, it may be more readily accepted as the product of market forces rather than a deliberate, isolated government decision.

If the unemployment and dislocations caused by plant shutdowns due to pollution control programs are judged unacceptable, the appropriate response is remedial: compensation programs should be designed to deal with unemployment and dislocation. We do not believe, however, that workers dislocated by environmental programs should be treated more favorably than those dislocated by the Federal Reserve Board's decision to restrict the money supply in order to fight inflation, or those imposed by competition generally.

19 See Levin, Getting There: Implementing the "Bubble" Policy, in SOCIAL REGULATION: STRATEGIES FOR REFORM (E. Bardach \& R. Kagan eds. 1982); Stewart, supra note 3. at 13091311, 1332-37; REGULATORY REFORM STAFF, U.S. EPA, EMISSIONS TRADING REPORT (May 10, 1984).

20 See infra text accompanying notes 27-28. 
these changing national guidelines to suit the particular conditions of every important pollution source in the United States. Instead of giving the job of economic and technological assessment to bureaucrats, the marketable rights mechanism would put this information-processing burden precisely where it belongs: upon business managers and engineers who are in the best position to figure out how to cut back on their plant's pollution costs. If the managers operating plant $A$ think they can clean up a pollutant more cheaply than those in charge of plant B, they should be expected to sell some of their pollution rights to $\mathrm{B}$ at a mutually advantageous price; cleanup will tend to occur at least cost without the need for constant bureaucratic decisions about the best available technology. While the reformed system may impose new regulatory tasks, it removes the greatest roadblock to administrative efficiency: it allows inevitably ill-informed bureaucrats to avoid technological and economic decisions best made by the people operating the plants.

Second, marketable permits would open up enormous financial resources for effective and informed regulation. While polluters would have the right to trade their permits among themselves during the $n$ years ${ }^{21}$ they are valid, they would be obliged to buy new ones when their permits expired at an auction held by the EPA in each watershed and air quality control region. These auctions would raise substantial sums of money for the government on a continuing basis. While no study has yet attempted to make global estimates for the United States as a whole, existing work suggests that auction revenues could well equal the amount polluters would spend in cost-minimizing control activities. ${ }^{22}$ Even if revenues turned out to be a third of this amount, the government would still be collecting more than $\$ 6-\$ 10$ billion a year. Moreover, it seems reasonable to suppose that Congress would allow the EPA (and associated state agencies) to retain a share of these revenues. Since the current EPA operating budget is $\$ 1.3$ billion $^{23}$ using even a fraction of the

21 All permits would not have to expire at the same time. For a discussion of systems that allow for variable time periods and differential privileges during emergency conditions, see T. TIETENBERG. supra note 9, at ch. 7; B. ACKERMAN, S. ROSE-ACKERMAN, J. SAWYER \& D. HENDERSON, supra note 9, at 268; J. DALES, supra note 9. at 95.

22 T. TIETENBERG, supra note 9, at 102-13, contains a comprehensive discussion of existing data. He concludes: "Of the 39 numerical entries [in his summary tables] permit expenditures are at least as great as control costs in 22 cases .... Large permit expenditures are the normal, rather than the exceptional, outcome." Id. at 106.

23 See David, Reagan Boosts EPA Funding, Slashes Interior Spending, 43 CONG. WEEKLY REP. 255 (1985). This figure excludes municipal water treatment subsidies and Superfund cleanup, but includes all regulatory programs, including pesticides, hazardous waste, drinking water and chemicals, as well as air and water pollution regulation. 
auction fund to improve regulatory analysis, research and monitoring would allow a great leap forward in the sophistication of the regulatory effort. Given its revenue-raising potential, environmental reform is hardly a politically unrealistic pipe dream. To the contrary, it is only a matter of time before the enormous federal deficit forces Congress and the President to consider the fiscal advantages of an auction scheme. ${ }^{24}$

Third, the auction system would help correct one of the worst weaknesses of the present system: the egregious failure of the EPA and associated state agencies to enforce the laws on the books in a timely and effective way. Part of the problem stems from the ability of existing polluters to delay regulatory implementation by using legal proceedings to challenge the economic and engineering bases of BAT regulations and permit conditions. But agencies also invest so little on monitoring ${ }^{25}$ that they must rely on polluters for the bulk of their data on discharges. Since polluters are predictably reluctant to report their own violations, EPA systematically generates a Panglossian view

24 Not that the political fight for an auction will be an easy one. Our market reform will be opposed by businesses who (despite their promarket rhetoric) will predictably resist the prospect of buying pollution rights after all these years of polluting for free. Nonetheless, reformist leadership would gain enormous popular support for a program proclaiming that the air and water of America belong to the people, and that polluters should pay if they wish to use it for limited periods.

While it is possible to design efficient auction systems that ameliorate, or eliminate entirely, the financial burdens imposed upon polluters, see T. TIETENBERG, supra note 9, at 100-13 (and sources cited therein), we would oppose these schemes on principle. We believe that just as firms are obliged to pay for other raw materials they require for their production process, they should be obliged to pay for the air and water they degrade. (Unlike current proposals to impose new taxes on all industries to finance toxic cleanup, tradeable permits would make sources pay in proportion to their contribution to pollution.).

The only exception we believe justified - for distributional and other reasons - is one for domestic waste processed by municipal sewage authorities. Congress could accomodate this interest by ordering EPA to give each municipality free permits based on the normal domestic waste produced by the average American. Cities could, of course, then make money by selling these rights to firms if private cleanup is relatively more expensive than public. In addition, Congress might well accomodate individual polluter interests by allowing a transitional period of free use, see supra note 18, in order to soften adjustment pains and reduce political opposition.

25 Total federal, state and local expenditure on air quality monitoring averaged only \$44 million a year during the four fiscal years between 1978 and $1981-.02 \%$ of the estimated costs of air pollution control during this period. See Crandall, supra note 5. at 220. Crandall goes on to report:

In 1979, the GAO reported that as many as 81 percent of all monitoring sites had one or more problems that could affect data reliability. In response, EPA developed a plan to assure that a total of more than five thousand monitors be sited and operated in a reliable fashion by federal, state, and local authorities. By the end of 1981, GAO reported that only about one-half of all monitors met EPA specifications. 
of regulatory reality. For example, a General Accounting Office investigation of 921 major air polluters officially deemed in compliance revealed 200, or twenty-two percent, to be violating their permits; in one region, fifty-two percent were out of compliance. ${ }^{26}$ Even when illegal polluters are identified, they are not effectively sanctioned. For example, the EPA's Inspector General in 1984 found that it was a common practice for water pollution officials to respond to violations by issuing administrative orders which effectively legitimize excess discharges. ${ }^{27}$

Thus, while the system may, after protracted litigation, eventually "work" to force the slow installation of expensive control machinery, there is no reason to think this machinery is being run well when it is eventually installed. Although there are many reasons for this appalling weakness in enforcement, one stands out above all others: the present system does not put the pressure on agency policymakers to make the large investments in monitoring and personnel that are required to make the tedious and unending work of credible enforcement a bureaucratic reality.

The auction system would change existing compliance incentives dramatically. It would reduce the opportunity and incentive of polluters to use the legal system for delay and obstruction by finessing the complex BAT issues, and it would limit dispute to the question whether a source's discharges exceeded its permits. It would also eliminate the possibility of using the legal system to postpone implementation of regulatory requirements by requiring the polluter that lost its legal challenge to pay for the permits it would have been obliged to buy during the entire intervening period of noncompliance (plus interest). ${ }^{28}$

The marketable permit system would also provide much stronger incentives for effective monitoring and enforcement. If polluters did not expect rigorous enforcement for the term of their permits, this fact would show up at the auction in dramatically lower bids: Why pay a lot for the

26 U.S. GEN. ACCT. OFFICE, IMPROVEMENTS NEEDED IN CONTROLLING MAJOR AIR POLLUTION SOURCES 9 (1979) (Report CEP-78-165).

275 INSIDE EPA (Report No. 11) at 6 (March 16, 1984). For other critiques of agency implementation efforts, see Roberts \& Farrell, supra note 16: Crandall \& Portney, supra note 8 al $42-49,69$.

28 In addition, a fine should be imposed if a polluter's discharges exceeded the permits it had acquired. Such a fine should be based not only on the extent of the excess but also its duration; $\$ x$ per unit of excess emission per day. While non-compliance penalties can be added on to a regulatory approach, see Drayton, Economic Law Enforcement, 4 HARV. ENVRL. L. REV. 1 (1980), they appear to have played a minor role to date. 
right to pollute legally when one can pollute illegally without serious risk of detection? Under a marketable permit approach, this problem would be at the center of bureaucratic attention. For if, as we envisage, the size of the budget available to the EPA and state agencies would depend on total auction revenues, the bureaucracy's failure to invest adequately in enforcement would soon show up in a potentially dramatic drop in auction income available in the next budgetary period. This is not a prospect that EPA administrators will take lightly. Monitoring and enforcement will become agency priorities of the first importance. Moreover, permit holders may themselves support strong enforcement in order to ensure that cheating by others does not depreciate the value of the permit holders' investments. ${ }^{29}$

A system of marketable permits, then, not only promises to save Americans billions of dollars a year, to reward innovative improvements in existing cleanup techniques and to eliminate the BAT system's penalty on new, productive investment. It also offers formidable administrative advantages. It relieves agencies of the enormous information-processing burdens that overwhelm them under the BAT system; it greatly reduces litigation and delay; it offers a rich source of budgetary revenue in a period of general budgetary stringency; and it forces agencies to give new importance to the critical business of enforcing the law in a way that America's polluters will take seriously. But, of course, there is no such thing as a free lunch in bureaucracy-land. Against these formidable advantages, the new system will generate new tasks. Are these new functions more or less onerous than the commandand-control operations that have been reformed away?

Begin by isolating four distinct bureaucratic functions required by the new system. First, the agency must estimate how much pollution is presently permitted by law in each watershed and each air quality region. Second, it must run a system of fair and efficient auctions in which polluters can regularly buy rights for limited terms. Third, it must run an efficient title registry in each region that will allow buyers and sellers to transfer rights in a legally effective way. Fourth, it must consistently penalize polluters who discharge more than their permitted amounts.

And that's that. So far as the fourth bureaucratic task is concerned, we have already given reasons to believe that the EPA would enforce the law far more effectively under the new regime than it does at present. So far

29 The opposition of New York taxi companies to competition by gypsy cabs without medallions shows that this is by no means a fanciful prospect. 
as the first three management functions are concerned, we think that they are, in the aggregate, far less demanding than those they displace under the BAT system. Taking the three functions in reverse order, we assume that everybody agrees that a system of title registration is within the range of bureaucratic possibility. In contrast, the second task - running fair and efficient auctions - is a complicated affair, and it is easy to imagine such a system run incompetently or corruptly. Nonetheless, other agencies seem to have done similar jobs in satisfactory fashions: If the Department of Interior can auction off oil and gas leases competently, ${ }^{30}$ we see no reason the EPA could not do the same for pollution rights. Finally, there remains the task of estimating the total allowable wasteload permitted under existing law in each watershed and air control region. If the BAT system functioned properly, these numbers would be easy to obtain. EPA's regional administrators would simply have to add up the allowed amounts appearing in the permits that are in their filing cabinets. We have no illusions, however, about present realities: So much bureaucratic time and energy has been diverted into the counterproductive factfinding tasks generated by the BAT system, and so little attention has been paid to actual discharges, that even the data needed for these simple arithmetic operations may well be incomplete and inadequate. Nonetheless, total permitted emissions in a region can be approximated in order to get a system of permits and auctions started. Surely this start-up effort would be less complex than the unending inquiries into available technologies required by existing law.

We believe that cries of bureaucratic chaos obscure the reality that the reformed system would be far more manageable than the existing one. While there would, of course, be costs and confusion in the transition, the three new tasks involved in running the reformed system seem, in the aggregate, a good deal easier than the bureaucratic functions they displace. Moreover, what little experience the EPA has had with market approaches supports this conclusion. All in all, the EPA has effectively discharged the bureaucratic tasks necessary to develop its market-based "bubble" and "tradeoff" control strategies under the Clean Air Act. These strategies create limited markets in pollution rights by: 1) allowing a new source to offset its new emissions by inducing an existing plant to reduce its discharges (this is the so called "tradeoff" policy);2) allowing an existing source that is expanding to reallocate control burdens among its

30 We are commenting here on the Department's technical success in running auctions, not on the substantive policies it has pursued in the past or present. 
existing and new units (new source bubble); and 3) allowing existing sources in the same region to reallocate control burdens (state implementation plan bubble). ${ }^{31}$ The use of these innovations was for many years clouded by legal uncertainties until the Supreme Court recently rejected challenges from some environmental groups. ${ }^{32}$ Despite this uncertainty, the Clean Air Act bubble policy alone, in limited use for only a few years, has achieved compliance cost savings of over $\$ 700$ million without any reduction (and in some cases an increase) in pollution control. ${ }^{33}$

More recently, the EPA has successfully instituted and managed a tradeable permit system among refiners in connection with an EPA-mandated phasedown of lead additives in gasoline. Refiners with higher lead-reduction costs buy lead rights from refiners with lower costs. All refiners file quarterly reports showing the lead content of their gasoline, as well as sales and purchases of rights with other refiners. Three-quarters of all refiners participate in purchases and sales of lead rights. The system will save hundreds of millions of dollars compared to uniform BAT commands. ${ }^{34}$

In short, limited real-world experiments suggest that market reform is well within modern bureaucratic capacities. Rather than using tradeable emission rights as a limited modification of BAT strategies, the bubble and tradeoff approaches should be generalized to permit regional trading of all air and water pollution permits. Moreover, the tradeable permit strategy should be used to deal with pollution problems-such as acid rain-that are currently unregulated and could be handled efficiently and effectively through economic incentives. ${ }^{35}$

31 See STEWART, supra note 9, at 13-14, and sources cited therein.

32 Chevron, U.S.A., Inc. v. Natural Resources Defense Council, Inc., 467 U.S. 837 (1984).

33 See T. TIETENBERG, supra note 9, at 52-56; sources cited supra note 10. Like any policy innovation, implementation of bubbles and tradeoffs raises numerous administrative and legal micro-problems. See LIROFF, THE BUBBLE POLICY AND EMISSIONS TRADING: THE TOLL AND TROUBLE OF REGULATORY REFORM (1985). As the Liroff study shows, many of these problems are caused by the effort to graft a limited system of tradeable pollution rights onto an existing regulatory system. Our proposal would entirely replace that system with tradeable rights, eliminating many of the complexities of a hybrid approach.

34 See OFFICE OF POLICY PLANNING AND EVALUATION, U.S. EPA, COSTS AND BENEFITS OF REDUCING LEAD IN GASOLINE: FINAL REGULATORY IMPACT ANALYSIS (1985).

35 See Stewart, supra note 9, at 14-15, and sources cited therein. Nor do we see any reason to limit the use of tradeable permits to the air and water pollution problems. As we suggest in the next section, hazards from toxic chemicals might appropriately be controlled through a system of "risk rights." Under this system, producers of new pesticides or other chemicals would purchase rights from existing producers or compete successfully for rights at one of the regular EPA auctions. Either way, the entry of new producers would force existing producers to reduce existing risk, thereby ensuring that the new product would not increase the total risk from chemicals faced by society. 
Would a system of marketable rights preclude improvement of environmental quality? By no means. The initial shock of rights can be amortized on a fixed schedule in order to reach a targeted goal, or the government may decide not to reissue existing rights after they expire. ${ }^{36}$

Any such reductions will increase the price of rights by reducing supply. Prices will also automatically tend to rise over time as the economy grows and demand for rights increases. Under a BAT approach, by contrast, regulators must consistently undertake new, difficult and unpopular initiatives to impose ever more stringent BAT controls on existing sources in order to accommodate economic growth without increased pollution. The prospect of steady increases in the price of rights will be a powerful incentivefar more powerful than the patchwork efforts at "technology forcing" under the BAT system-for businesses to develop cleaner products and processes.

A more serious objection to our proposal is that it ignores the problem of defining the region within which trades are permitted. The short answer is that the EPA and the states have already divided the nation into several hundred air quality control regions; similarly, the states have delineated the watershed boundaries for pollution control and other water management purposes. ${ }^{37}$ Rather than starting from scratch, reform can proceed on the basis of these existing boundaries. Especially in the area of air pollution, however, we have no doubt that existing regional lines have been drawn in a way that is extremely insensitive to ecological realities. ${ }^{38}$ We strongly recommend, therefore, that a reformed statute provide a mechanism for the orderly reexamination of existing regional boundaries-although it may well be wiser to defer this question for five or ten years to allow the EPA to concentrate on the challenge involved in managing the transition to a marketable permit system.

Even after regional boundaries have been redefined in a more ecologically sensitive way, moreover, there will remain much more potential for bureaucratic refinement by future reformers. In particular, the market system

36 See supra note 21.

37 Most major lake and river systems are the subject of intense water quantity and quality management under watershed systems established under state law or interstate, compacts. We would establish the geographic boundaries of water pollution permit markets by reference to these systems.

38 They typically follow state lines, for example, leading to extremely unwieldy efforts by courts to take interregional impacts into account. See. e.g., Connecticut v. EPA, 656 F.2d 902 (2d Cir. 1981); New England Legal Foundation v. Costle, 632 F.2d 936 (2d Cir. 1980) (per curiam). 
we have described could allow the creation of relatively high concentrations of particular pollutants in small areas within the larger pollution control region. In tolerating "hot spots," of course, our reform proposal shares the defects of the existing BAT system, which also ignores problems by imposing the same controls on sources regardless of their location, the size of the human population affected by their discharges, and the nature and vulnerability of affected ecosystems. ${ }^{39}$ Nonetheless, the reformed system's blindness to intraregional variation is a serious source of concern to us; we believe that a long-run strategy for institutional reform should strive to develop a regulatory infrastructure that will ultimately allow a sophisticated response to the problem. The extensive literature on marketable permits points to a variety of feasible means of dealing with the hot spot problem. ${ }^{40}$ We believe that a longrun strategy for institutional reform should strive to take advantage of these more sophisticated market solutions to the problem of intraregional variation. For the present, though, it seems wisest to defer a serious confrontation with these problems to the next round of reform in the year 2000 or so-when more of the regulatory building blocks have been put into place.

The critical question today is not whether a market reform fails to solve problems that the BAT system also fails to solve. It is whether the reformed implementation system will generate new problems that offset its great economic, environmental and administrative advantages. ${ }^{41}$ Nothing we can see substantiates this fear. While the reform does require bureaucrats to do

39 Existing federal laws contain some provisions to prevent excessive local environmental damage from sources that already comply with BAT standards. But these provisions have not been effectively implemented. We believe that an important reason for this failure is the diversion of bureaucratic energies into BAT determinations. Once liberated from the exhausting demands of comprehensive command-and-control, it may be possible for the EPA to design crude, but useful, mechanisms which can realistically respond to "hot spots." All we can do here, though, is to flag this problem of statutory design as deserving high priority on the reform agenda.

40 See T. TIETENBERG, supra note 9. at 64-86, and sources sited therein.

41 Here are two potential problems worthy of mentioning: we can foresee situations in which existing polluters might try to manipulate the rights market to deter entry by new firms in a way inconsistent with the anti-trust laws, either by monopolizing the pollution rights market itself, or by using it to block entry by competitors. See, e.g., T. TIETENBERG, supra note 9, chs. 4, 6, \& 7 and sources cited therein; Rose-Ackerman, Market Models for Water Pollution Control: Their Strengths and Weaknesses, 25 PUB. POL'Y 383 (1977); B. ACKERMAN, S. ROSEACKERMAN, J. SAWYER, \& D. HENDERSON, supra note 9, at 275-81; Stewart, supra note 3, at 1336. Administrative authorities may also have to play a "market-maker" role in the rights market in order to ensure an adequate supply of rights at all times and smooth out price fluctuations, see J. DALES, supra note 9, at 94-95, although it is possible that private institutions could discharge these functions. 
some new things, these tasks seem far more manageable than the exhausting command-and-control functions they replace.

\section{Toward democratic dialogue}

So far we have been approaching reform in the much-maligned mode of the social engineer-offering to build you a better mousetrap, as it were, than the Rube Goldberg model now in operation. While we do not join in the fashionable disdain for such matters of "instrumental rationality," there is obviously more to political life than building efficient bureaucratic machines. The ultimate political questions involve ends, not means: How important is a healthy environment anyway? It isn't enough to say "very," since environmental quality is a very expensive good, which must compete with other precious public values-education, welfare, social security, etc. Somehow or other tough choices must be made: When should we stop pouring money into a clean environment to make room for a first-rate educational system or... How much is enough?

Our basic problem with the BAT system is that it discourages a serious political encounter with such questions. BAT focuses Congressional debate, as well as administrative and judicial proceedings, upon arcane technological questions which rapidly exhaust the time and energy that most politicians, let alone the larger public, are willing to spend on environmental matters. In contrast, the marketable permit system will allow the policymaking debate to take a far more intelligible shape. Rather than debating the difference between the "best available control technology" and "lowest achievable emission rate," 42 citizens may focus upon a different question when the environmental acts come up for revision: During the next $n$ years, should we instruct the EPA gradually to decrease (or increase) the number of pollution rights by $x$ percent? Environmentalists will, of course, argue for big reductions; others, who are more impressed with the costs of control, for smaller reductions or even selective increases. But at least the Congressional debate would be encouraged to focus upon the fundamental question: Speaking broadly, do the American people believe existing environmental objectives to be too

42 See Clean Air Act $\S 165$ (a)(4), 42 U.S.C. $\S 7475$ (a)(4) (BAT requirements applicable to new sources in prevention of significant deterioration areas); Clean Air Act $\S 171(3), 42$ U.S.C. $\S 7501(3)$ (BAT requirements applicable to new sources in nonattainment areas). 
ambitious (in which case Congress should increase the number of rights) or do we think that we should further cut back on pollution (by cutting back on the number of rights)?

There is, of course, no single technocratic answer to this question. That's precisely why it should be the focus of political debate. The great virtue of the marketable permit program is that it puts the question in an operational form accessible to the general public.

An analogy from a very different policy area may be instructive. Imagine that the Labor Department refused to report an Unemployment Rate each month. Instead, when it was asked about the employment situation, it inundated its audience with stories about how workers in one or another industry might be displaced by one or another technology. While such stories are informative, wouldn't there be a great danger that the general public, and Congress, would miss the forest for the trees? The preeminent question, after all, that generalist decisionmakers can and should answer is how much overall unemployment is tolerable. And for this purpose, the unemployment rate functions as a key control variable. The same holds true in environmental policy: a vote on a proposal to change the overall number of pollution permits would be a vehicle for the democratic formulation of policy superior to any generated by the existing BAT regulatory system.

\section{A. A Short-Term Strategy: Redesigning Statutory Variables}

To put the point more legalistically, we propose the use of new statutory control variables in the design of our environmental statutes. Rather than speaking in technology-based terms, the key statutory variables would be pollution-based. More precisely, they would specify the rate of change in existing levels of pollution that Congress wishes to achieve during the period until the Act once more comes up for Congressional reconsideration. Under the revised system, Congress would no longer content itself with mounting pieties about the need to achieve "reasonable further progress" 43 in environmental protection. It would instead specify, in quantitative terms, how much change is "reasonable" by voting for an $n$ percent reduction (or increase) in the number of aggregate permits EPA would be allowed to auction off annually to

\footnotetext{
43 See Clean Air Act § 171(1), 42 U.S.C. § 7501(1).
} 
the nation's polluters. ${ }^{44}$ This single change, we believe, would vastly increase the degree to which critical questions of environmental policy can be framed in a way that is transparent to the general public.

This change, however, is only the first step toward more democratic decisionmaking: because it is limited to upward or downward adjustment of the aggregate pollution levels permitted under the existing system of uniform federal standards, it does not allow for more discriminating regulation of particular pollution problems. We see no reason, however, for Congress to content itself with such crude uniformities. For example, within the general context of a twenty percent rights reduction, Congress might target certain pollutants for a forty percent reduction, while allowing others to be reduced by only five percent. Similarly, Congress may well announce principles concerning the way in which the reductions should be allocated across the nation: For example, should stricter cut-backs be scheduled in areas violating primary or secondary health standards? In ecologically sensitive areas? If so, by how much?

Such decisions would require Congresspersons, and their constituents, to guess about countless contestable matters involving both facts and values. The fact is, however, that these uncertainties already exist, and it is precisely because they cannot be resolved technocratically that they should be framed in a way that invites self-conscious political decisions by the Congress. In contrast, the BAT system fails to focus attention on the overall rate America should clean up the environment, leaving it to unguided and disjointed bureaucratic decision in an endless series of BAT inquiries into the "availability" of one or another cleanup technology.

\section{B. Long-Term Strategies: Toward Decentralization and Constrained Cost-Benefit Analysis}

We now have all the makings for a serious reform proposal. By combining pollution-based statutes with market-based incentives, we have done more than build a better mousetrap. We can glimpse a regulatory structure that will encourage a focused debate over our environmental commitments, as well as

44 See J. KRIER \& E. URSIN, supra note 6 (authors proposed similar reduction schedule to deal with noncompliance with federal air quality standards under Clean Air Act). 
a statutory mechanism for registering the evolving democratic consensus on the urgency of environmental priorities.

As this section will suggest, such a pollution-based market incentive scheme leaves a lot to be desired from a more Utopian perspective. Nonetheless, it is a mistake to try for too much too soon, especially since a "first generation" reform will itself generate valuable experience that may make proposals that seem Utopian now far more realistic in fifteen or twenty years.

Thus, if we're still around in the year 2000, we hope to be advocating a "second generation" reform: Congress should create a statutory foundation for legally constrained cost-effectiveness analysis. Like the first-generation approach, this second-generation statute would express itself in terms of a change-oriented pollution-based command. To fix ideas, imagine that the reformed statute mandated a twenty percent reduction of allowable pollution levels over the next ten years. In contrast to our "first generation" approach, however, the statute would not insist that the twenty percent cutback be obtained in each and every part of the country, or in those areas specified by Congress. Instead, EPA would be given discretion to allocate the cleanup effort. So long as an average twenty percent cutback was achieved, the statute Would-allow the EPA to force some areas to cut back up to thirty percent whileallowing others to cut back only ten percent-provided that the agency could support its judgment with a thoughtful cost-benefit analysis indicating that such variations within the twenty percent average will lead to cutbacks where they will do the most good.

In allowing for limited regional variation, this second-generation reform would be making a final break with the BAT insistence upon nation-wide uniformity. We believe that uniform goals are seriously dysfunctional, producing too much control in some regions, too little in others, and completely missing special problems elsewhere. A notorious example of mindless uniformity is the effluent limitations imposed by the present Clean Water Act, which have required the same level of cleanup by all plants in a given industry, regardless of whether a plant discharges into an ocean or large lake where they will have little or no effect, or into a pristine river. ${ }^{45}$

45 See, e.g., Appalachian Power Co. v. EPA, 671 F.2d 801 (4th Cir. 1982). The original system of nationally uniform ambient air quality standards in the Clean Air Act, § 109, 42 U.S.C. 4 7409, have been transformed into a nonuniform system by subsequent amendments, that recognize the difficulty of achieving the standards in nonattainment areas, see Clean Air Act 44 171-78, 42 U.S.C. $\S 7501-08$, and the desirability of prevention of significant deterioration (PSD) in clean air regions, see Clean Air Act $\$ \S 160-69$ A, 42 U.S.C. \$§7470-79, 7491. The nonattainment 
This blindness to environmental reality - which is replicated in many other areas $^{46}$-is a parody of the ecological consciousness that should motivate sound policymaking.

Before taking this step, however, we must first construct much stronger regional institutions than now exist in the present, overcentralized federal systems. We look forward to a day when we might go to any region in the country and find a serious professional staff that could both describe the existing environmental data and models, and explain how it proposes to improve them over the next five or ten years. Without such an ongoing system of data collection and analysis, there can be little hope of designing regulatory systems which are sensitive to regional ecological and economic realities. ${ }^{47}$ Indeed, if an effort at regional institution-building had been inaugurated fifteen years ago with the enactment of the key Air and Water Acts, we would no longer be obliged to make policy in the blindly uniformitarian way we do today.

It is wrong, moreover, to assume that our failure to construct the requisite regional infrastructure is simply a result of tight EPA budgets. ${ }^{48}$

and PSD systems are not based, however, on ecological and health realities, but on the happenstance of BAT implementation and the historical accident that some regions have been less industrially developed, and therefore less polluted, than others.

46 Consider recent congressional proposals to deal with toxic pollution problems by mandatory uniform BAT controls on industrial sources. For example, H.R. 2576, 99 Cong.; 1st Sess. (1985), introduced by Congressmen Wirth, Waxman and Florio, would require the EPA to set stringent BAT standards for 85 named chemical substances, plus any additional substances that might contribute to serious illness. Any citizen could petition the EPA to designate a substance, and the EPA would be required to respond within 180 days. If the EPA failed to set stringent standards for any such substance within two years, the applicable standard would be "no detectable release." This is the use of an indiscriminate BAT strategy with a vengeance, ignoring evidence suggesting that many problems are localized ones in which nonindustrial sources play a major role. See E. HAEMISEGGER, THE AIR TOXIC PROBLEM IN THE UNITED STATES: AN ANALYSIS OF CANCER RISKS FOR SELECTED POLLUTANTS (EPA-450/I-85-00I) (1985); U.S. ENVIRONMENTAL PROTECTION AGENCY, A STRATEGY TO REDUCE RISKS TO PUBLIC HEALTH FROM AIR TOXICS (June 1985). See also Harrington, Krupnick \& Peskin, Policies for Nonpoint-Source Water Pollution Control, 40J. SOIL \& WATER CONSERVATION 27 (1985).

47 What we propose is the modern-day equivalent of the plan, aired but never pushed in Franklin Roosevelt's second term, for a series of regional TVAs throughout the nation. See B. KARL, THE UNEASY STATE: THE UNITED STATES FROM 1915 TO 1945 at 164-67 (1983).

48 See supra note 25, for the paltry sums that are presently invested in the effort to monitor environmental realities. It is, of course, no easy matter to create strong regional authorities within our political system. But the TVA experience suggests that the federal government can most readily promote such authorities by endowing them with economic resources and responsibility for their management. By contrast, it is far more difficult to create new authorities with the power, customarily reserved to the national and state governments, to issue and coercively enforce legally binding orders. Accordingly, the shift in tools from BAT 
The agency, after all, has spent plenty of time and money engaging in a fact-finding inquiry into the state of the best available technology. The reason for the infrastructural failure is that ongoing and careful region-byregion study is irrelevant to the regulatory effort as defined by the present BAT system. To change agency incentives, a reformed law might expressly contemplate a more sophisticated form of auction to commence at some future point in time, say ten or fifteen years after enactment. Under these "second generation" auctions, the EPA could allow different regions of the country to cut back permitted quantities by different amounts on the basis of a thoughtful cost-benefit analysis; similarly, each regional authority would be allowed to vary cut-backs within its region to take special conditions into account. ${ }^{49}$ At no point, however, would we endorse unfettered cost-benefit analysis. Congress would continue to stipulate an allowable range of variation around national norms that could be justified through regional cost-benefit analysis.

\section{Priority Setting}

A final set of reforms involve the way in which BAT distorts the process by which new priorities are established in the light of changing information about environmental realities. BAT discourages intelligent priority setting for two related reasons. First, the EPA is so overwhelmed by fact-finding tasks required to implement a technology-based approach that it has relatively few resources left for exploration of risks posed by new pollutants. Second, BAT imposes heavy bureaucratic costs on the EPA every time it recognizes a new threat to the environment. For, once a new pollutant has been identified, BAT requires the agency to exhaust itself with yet another series of never-ending inquiries into the state of control technology in each of the industries that have been discharging the "newly discovered" pollutant, and to establish an elaborate set of new industry-by-industry standards. Moreover, once a pollutant has been targeted for regulation, BAT automatically requires

commands to transferable pollution permits-the federally created resource which the proposed new authorities would manage-will facilitate the development of regional institutions.

49 Of course, if the agency did not exercise its discretion, or if its regional variances did not survive judicial review, the national average (in our example, 20\%) would apply in the regions affected. Given its long-term perspective, a second-generation statute could also provide a schedule that would contemplate a lengthy period for administrative rulemaking and judicial review. 
imposition of controls to the full extent of available technology $y^{50}$ - a potentially enormous commitment of compliance resources that may not be justified by the benefits achieved and that is likely to be strongly opposed by industry through protracted litigation. It should be no surprise, then, that the EPA has, in fact, been very reluctant to expand the number of its pollution targets. ${ }^{51}$

The administrative inertia generated by BAT was, perhaps, of secondary concern so long as one could believe that environmental degradation was the product of a few widespread pollutants, each of which should be controlled to the greatest extent feasible within a period of years. After two decades of practical experience with environmental regulation, however, it should be clear that there are thousands of substances that pose at least some risk and that we cannot deal with all of them simultaneously. The defect of the BAT system is that it tends to select out, more or less arbitrarily, a relatively few pollutants and devotes enormous administrative and control resources to regulating them to the hilt.

The reforms we have already advocated will create new incentives for the innovative priority setting that is needed in today's world. First, a statute whose control variables were pollution based, rather than technology-based, would encourage a more focused discussion on whether the goals set for different pollutants reflect sensible priorities. Indeed, it is not fanciful to

50 "Available technology" is an elastic concept. In many instances, including most cases of water pollution, technology is available in an engineering sense to eliminate pollution entirely. If we were willing to spend hundreds of billions of dollars, we could have drinking water flowing from industrial waste discharge pipes (although disposing of the pollutants removed from waste streams could present serious problems). Accordingly, most decisions about "available" technology must-implicitly or explicitly-take costs into account. The significance of costs cannot be determined in isolation from benefits. The vice of the BAT strategy is that it ignores this inevitable cost-benefit consideration, or at best buries it, by treating it as an engineering decision about technological feasibility.

51 Courts have empowered environmental plaintiffs to force agency action upon presentation of a prima facie case that a currently unregulated pollutant presents a substantial hazard, see Environmental Defense Fund. Inc. v. Ruckelshaus, 439 F.2d 584 (D.C. Cir. 1971), and Congress has codified these rulings in "action-forcing" statutory "citizen suit" provisions. See, e.g., Clean Air Act § 304; 42 U.S.C. § 7604; H.R. 2576, supra note 45. While agency inaction is, as we have noted, a serious problem under a BAT regime, the reliance on "action-forcing" through litigation may well be a cure worse than the disease. Such a strategy invites a "pollutant of the month" approach to priority setting. There is no assurance that the initiatives selected by different environmental groups will result in a sensible allocation of limited administrative and compliance resources. The Supreme Court's recent decision in Heckler v. Chaney, 105 S.Ct. 1649 (1985) may reduce "action-forcing" litigation in the context of regulatory statutes that do not contain citizen suit provisions. See generally Sunstein, Reviewing Agency Inaction After Heckler v. Chaney, 52 U. CHL L. REV. 653 (1985). But this would merely alleviate symptoms of the current BAT system without providing any positive incentives for intelligent priority setting. 
suppose that a risk portfolio strategy eventually might emerge that would explicitly attempt to rank the comparative risks confronted by an EPA or an OSHA and then seek to determine how available administrative and control resources might best be devoted to maximizing the reduction of risks in a given time period. ${ }^{52}$ Such a strategy need not be limited to pollution. It could also be used, for example, to manage the risks posed by pesticides, chemicals or hazardous wastes. ${ }^{53}$

Second, the adoption of a marketable permit scheme would dramatically change bureaucratic incentives involved in a decision to target a new pollutant. Rather than ignoring new problems in an effort to avoid BAT burdens, the agency may well gain additional bureaucratic resources by altering its regulatory priorities-for recall that our statutory reform would reward the agency with a share of any auction revenues any new regulated pollutant might generate. Indeed, given its budgetary rewards, a critic might fear that our proposals would generate an equal and opposite danger from the one prevailing under the current regime: why wouldn't the EPA be transformed into a hyperactive agency, eager to maximize its budgetary revenues by expanding its concern to "pollutants" that do not in fact threaten any serious risk to ecological or human values?

While hyperactivity is a danger, its seriousness should not be exaggerated. After all, every large bureaucratic organization experiences a great deal of difficulty redefining its priorities. Given the reality of bureaucratic inertia, and the fact that industry will continue to resist new initiatives (particularly when it must pay for the right to pollute), ${ }^{54}$ we believe that it is wiser to offer budgetary rewards for innovative priority setting rather than allow BAT to reinforce bureaucratic reluctance to take changing environmental realities into account.

52 In order to reduce some of the administrative and other problems involved in establishing separate permits and markets for many different pollutants, a "mutual fund" variant of the portfolio approach might be used, where appropriate, to control related pollutants through permits based on a weighted average of volume and risk.

53 Development of such strategies will take considerable time, and there will inevitably remain discrete sources of risk that must be dealt with through command-and-control standards or screening procedures. In these limited contexts, regulatory negotiation may be a promising mechanism for promoting more informed regulatory decisionmaking that is sensitive to the magnitude of various risks and the practical problems of managing them.

54 Industry pressure will also operate to offset EPA's reluctance, for fiscal reasons, to increase the number of permits for a pollutant already being regulated when new evidence shows that the risks it poses are not nearly as great as originally believed. 
The proposed shift in bureaucratic incentives, however, does reinforce the need for a regulatory structure that endorses thoughtful cost-benefit analysis in the priority-setting process. Up to the present time, legislators have been able to indulge in absolute-seeming statutory prohibitions on all harmful pollutants because they could count on regulatory lethargy and the covert consideration of costs in defining BAT to blunt statutory calls for all-out war on pollution. Once a reformed statute has changed the balance of incentives for bureaucratic innovation, however, it should insist on cost-benefit analysis before a new pollutant is made the subject of a marketable permit auction. The critical question, in each case, should be whether there is reason to believe that increasing discharges of the pollutant over existing levels generates more environmental harm than its marginal control will cost. (For these purposes, costs, like benefits, should not be measured in any mechanical way, and will inevitably involve large social judgments.) If so, the "new" pollutant should be regulated on the basis of the same pollution-based principles we have elaborated previously; if not, not. Of course, even if an agency refused to list a new pollutant, Congress would be free to force it to change its mind the next time the governing statute is reappraised. ${ }^{55}$ Once again, cost-benefit analysis would be subordinated to democratic decision.

Finally, all steps toward more intelligent priority setting need not be delayed until the adoption of some of the more far-reaching reforms we have advanced. It should be emphasized, moreover, that cost-benefit analysis is not, as some environmentalists too easily suppose, a code-word for regulatory passivity. A stunning counter-example is EPA's recent decision substantially to eliminate lead additives in gasoline. The key to this decision was an economic analysis performed in EPA's Office of Planning and Policy evaluation showing that the move would achieve major health benefits at little or no net cost. ${ }^{56}$

We should also encourage the EPA to use fully the information which does exist, but which is ignored by regulators who refuse to confront ecological and economic realities. EPA, for example, routinely develops information on the costs of control and the reduction in pollution or risk per dollar of

55 Given the need for agency flexibility in priority setting and the dangers of judicial inculcation of the "pollutant of the month" syndrome, we would exclude full-scale judicial review of decisions whether or not to initiate regulatory action against particular substances in all but extreme cases of arbitrariness, provided that a regulatory agency had developed an informed and reasonable process of priority setting under which the refusal to act in a particular case could be justified.

${ }^{56}$ See supra note 34. 
compliance expenditures for different industries. ${ }^{57}$ It simply has failed to use available information to make the allocation of burdens among industries more cost effective or target resources to the highest priority problems. Recent changes in EPA's approach show that such steps are feasible. For example, EPA recently decided not to regulate emissions of acrylonitrile and other toxic emissions under section 112 of the Clean Air Act when analysis showed that the risks involved were relatively low compared to the more serious problems posed by chromium emissions - which it did decide to regulate. ${ }^{58}$ Such examples show that it is feasible to do a better job of goal-setting-by introducing cost-effectiveness considerations in evaluating control options for different risks and setting priorities more intelligently-even within the existing BAT system.

Steps such as these will not necessarily impose greater burdens on administrators from the BAT approach that presently prevails. ${ }^{59}$ Even when they do involve additional burdens for administrators, that fact alone cannot condemn them. The question is whether increased administrative costs are outweighed by greater benefits for society as a whole. The development by EPA of the bubble and tradeoff policies required additional informationgathering, analysis and other effort. But the payoff has been enormous. The bubble alone has saved over $\$ 700$ million $^{60}$ and inspired new ways of cleaning up pollution. To focus on administrative costs, without considering the societal benefits of more intelligent regulation, produces penny-wise and pound-foolish public policies.

57 See, e.g., Crandall, supra note 5, at 214-15 (EPA data reproduced in table 8.1).

58 See EPA to List Chromium Under Section 112, Decides Not to List Four Other Substances, 16 ENV'T REP. [CURRENT DEVELOPMENTS] 236 (June 7, 1985): Harrison, Haig \& Nichols, supra note 8.

59 For example, in the 1972 Federal Water Pollution Control Amendments, Congress imposed uniform technology-based standards in order to avoid the transaction costs and implementation problems involved in policing environmental quality standards. In order to simplify decisionmaking, the 1972 Act ignored variations in water quality uses and goals. In implementing the Act, however, the EPA felt compelled to consider cost and other variables indirectly in setting BAT standards. This indirect approach caused the EPA to set separate standards for over 500 different industries and subindustries, a majority of which were challenged in court. Long delays in implementing the statutory scheme resulted. See also S. MELNICK, supra note 7, at 193-205 (chronicling problems in adjusting the uniform federal air quality standards to differing local and regional circumstances).

60 See supra note 33 and accompanying text. 


\section{Conclusion}

In urging fundamental reform of environmental law, we do not mean to disparage the very great achievements of the generation that enacted sweeping federal legislation in the late 1960s and the early 1970s. Apart from the many unambiguous achievements of this statutory revolution, even the embrace of a BAT approach made some sense as a crude first-generation strategy. During the early days of serious federal concern, perhaps it was plausible for politicians to suppose that only a few pollution problems were out of hand, and that these problems could be "solved" in a short time by an all-out war against "pollution." From this perspective, it could seem plausible to try to force everyone to adopt the best available technology everywhere.

Our complaint is not with the draftsmen of the early 1970s, but with politicians and environmental lawyers of the late 1980s who fail to put these early statutes in historical perspective. ${ }^{61} 61$ Two decades of intensive federal regulation emphasize that the environmental risks we confront are very numerous and vary widely in seriousness. Our strategies for managing these risks must set intelligent priorities, make maximum use of the resources devoted to improving environmental quality, encourage environmentally superior technologies and avoid unneeded penalties on innovation and investment. Rather than wringing our hands helplessly before these complexities, the challenge is to incorporate maturing perceptions about our regulatory problem into the evolving legal structure-and help our fellow Americans build a system that will not only save tens of billions of dollars a year, but make environmental law more democratically accountable and bureaucratically effective. It is past time for environmentalists to stop celebrating the statutory revolution of the 1970s, and start building a statutory structure worthy of the year 2000 .

\footnotetext{
${ }^{6161}$ For another effort to put these statutes in perspective, see Elliott, Ackerman \& Millian, Toward A Theory Of Statutory Evolution: The Federalization of Environmental Law, I J. LAW, ECON. \& ORG. 313 (1985).
} 


\section{References}

ANDERSON. Marketable Pollution Permits and Acid Rain Externalities, 16 CAN. J. ECON. 704 (1983).

ACKERMAN; STEWART. "Reforming Environmental Law”, Stan. L. Rev., v. 37, 1333, 1985.

ASHFORD; AYRES; STONE. Using Regulation to Change the Market for Innovation, 9 HARV. ENVTL. L. REV. 419 (1985).

CRANDALL. The Political Economy of Clean Air. Practical Constraints on White House Review in ENVIRONMENTAL POLICY UNDER REAGAN'S EXECUTIVE ORDER 205, 215-221.

; PORMNEY. Environmental Policy, in NATURAL RESOURCES AND THE ENVIRONMENT: THE REAGAN APPROACH 48-49, 72-73.

DAVID, Reagan Boosts EPA Funding, Slashes Interior Spending, 43 CONG. WEEKLY REP. 255 (1985).

DORFMAN, The Lessons of Pesticide Regulation in REFORM OF ENVIRONMENTAL REGULATION 13 (W. Magat ed. 1982).

DRAYTON, Economic Law Enforcement, 4 HARV. ENVRL. L. REV. 1 (1980).

ELLIOTT; ACKERMAN; MILLIAN. Toward A Theory Of Statutory Evolution: The Federalization of Environmental Law, I J. LAW, ECON. E ORG. 313 (1985).

HARRINGTON, KRUPNICK; PESKIN. Policies for Nonpoint-Source Water Pollution Control, 40J. SOIL \& WATER CONSERVATION 27 (1985).

HARRISON; HAIG; Nichols. Benefits Assessment and Environmental Regulation: Case Studies of Hazardous Pollutants, in ENERGY AND ENVTL. POLICY CENTER, JOHN F. KENNEDY SCH. OF GOV'T, HARV. U., DISCUSSION PAPER SERIES E-83-07 (1983).

HUBER. The Old-New Division in Risk Regulation, 69 VA. L. REV. 1025 (1983).

KALT. The Impact of Domestic Environmental Regulatory Policies on U.S. International Competitiveness, in ENERGY AND ENVTL. POLICY CENTER, JOHN F. KENNEDY SCH. OF GOV'T, HARV. U., DISCUSSION PAPER SERIES E-85-02 (1985). 
KRIER. The Irrational National Air Quality Standards: Macro and MicroMistakes. 22 UCLA L. REV. 323 (1974).

LATIN. Ideal Versus Real Regulatory Efficiency: Implementation of Uniform Standards and "Fine Tuning" Regulatory Reform, 37 STAN. L. REV. 1267 (1985).

LEVIN. Getting There: Implementing the "Bubble" Policy, in SOCIAL REGULATION: STRATEGIES FOR REFORM (E. Bardach \& R. Kagan eds. 1982).

PASHIGIAN. The Effect of Environmental Regulation on Optimal Plant Size and Factor Shares, 27 J.L. E ECON. 1 (1984).

PEDERSEN. Why the Clean Air Act Works Badly, 129 U. PA. L. REV. 1059 (1981).

ROBERTS; FARRELL. The Political Economy of Implementation: The Clean Air Act and Stationary Sources, in APPROACHES TO CONTROLLING AIR POLLUTION, 152.

ROSE-ACKERMAN. Effluent Charges: A Critique, 6 CAN. J. ECON. 512 (1973). . Market Models for Water Pollution Control: Their Strengths and Weaknesses, 25 PUB. POL'Y 383 (1977).

STEWART. On Explaining the Development of "Emissions Trading" in U.S. Air Pollution Policy, 7 L. E Pol'y 447 (1985).

_. Regulation, Innovation and Administrative Law: A Conceptual Framework, 69 CALIF. L. REV. 1259, 1265-66 (1981)

. The Discontents of Legalism: Ongoing Relations in Administrative Regulation, 1985 Wis. L. Rev. 655. 